\author{
S.U. Tleukenova ${ }^{1}$, D.Sh. Baigarayev ${ }^{1}$, S.N. Atikeyeva ${ }^{2}$, A.K. Ramazanov ${ }^{1}$, \\ H.A. Gavrilkova ${ }^{1}$, R.T. Musina ${ }^{1}$ \\ ${ }^{I}$ Karagandy University of the name of academician E.A. Buketov, Kazakhstan; \\ ${ }^{2}$ University «Turan-Astana», Nur-Sultan, Kazakhstan \\ (*E-mail: damir--6@mail.ru)
}

\title{
Development of methods of cryopreservation of Verbascum officinalis' seeds
}

\begin{abstract}
Introduction into the cryogenic collection of medicinal plant seeds allows maintaining their viability for a long time. However, there are no universal protocols for freezing seeds of plants; so for each species, the freezing and defrosting conditions need to be selected individually. The purpose of the present studies is to determine the main conditions for cryopreservation of the seeds of the medicinal plant Verbascum officinalis. During the development of the cryopreservation condition, optimal freezing containers, defrosting temperature, pre-freezing humidity of seeds and optimal cryoprotectors were selected. The results of the studies showed that the maximum germination rates of seeds and germination energy were obtained using plastic containers, seeds humidity of $3 \%$, defrosting in a water bath. The optimal cryoprotector is DMSO in concentration $5 \%$. The results made it possible to introduce Verbascum officinalis into the cryogenic collection of seeds of medicinal plants.
\end{abstract}

Keywords: medicinal plant, Verbascum officinalis, germination rate, energy of germination, seed humidity, cryopreservation, type of container, defrosting, cryoprotertors.

\section{Introduction}

Kazakhstan has adopted a policy of developing the main industries, one of which is pharmaceutical. In the Republic, the total production of medicines can meet the needs of the population at the level of 7-10\%. The rest of the medicines are imported from the countries of the near and far abroad [1].

The development of the medicinal plant industry poses a large number of tasks for researchers, including the organization of a seed storage system.

Seed storage is a complex process, during which it is necessary to ensure satisfactory germination and seed germination energy for as long as possible [2-4].

During storage, the seeds continue to undergo physiological processes of respiration, metabolism, oxidation, and others. The cells and intercellular space accumulate decay products, free radicals, which contribute to cell aging and reduce seed germination $[5,6]$.

In recent decades, cryopreservation has been a promising direction for preserving plant seeds. Storage in liquid nitrogen (or vapors of liquefied nitrogen) almost completely inhibits the physiological processes in the body, thereby preventing the accumulation of radicals and decay products, providing an almost unlimited storage period $[7,8]$.

Therefore, for the organization of the seed storage system, it is necessary to optimize a number of factors, such as freezing conditions (shock or step cooling), freezing containers (plastic, metal or paper), thawing conditions, the type and concentration of cryoprotectors.

The purpose of this study is to determine the degree of survival of the seed material of Verbascum officinalis depending on the conditions of cryopreservation.

\section{Objects and methodology}

The object of research was the seed material and seedlings of plants Verbascum officinalis. The seeds were collected on the collection of natural flora of the Mangyshlak experimental Botanical garden and 20172020. The research was conducted on the basis of the laboratory of biotechnology and molecular genetics of the faculty of biology and geography of E.A. Buketov Karaganda State University.

The seed material was dried to various degrees of humidity, Packed in paper containers and stored for 2.5 years. Quarterly samples were taken and evaluated for germination and germination energy.

The study of germination and seed germination energy was carried out according to the methodological instructions of M.S. Zorina and S.P. Kabanov [9], M.V. Maltseva [10]. The morphology of seeds and seed- 
lings was studied using a binocular microscope MBS-1 in laboratory conditions at a magnification of 40-80 times. Seeding was performed on Petri dishes on 2-layer filter paper moistened with distilled water.

When organizing a cryopreservation experiment, seeds were divided into batches and packed in 2 types of containers: plastic and aluminum foil bags (Fig. 1).

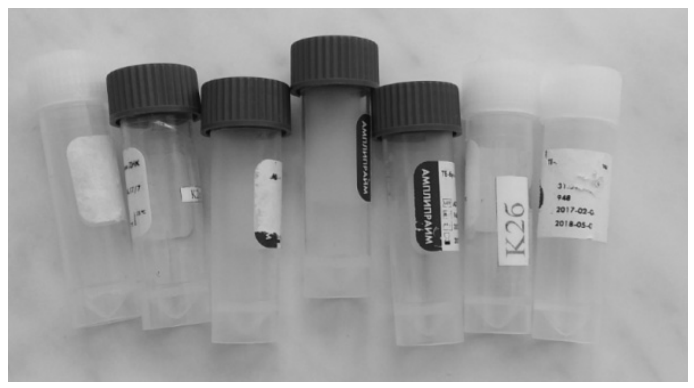

$A$

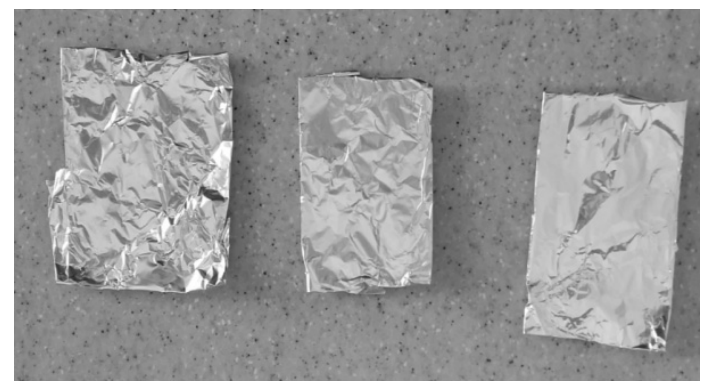

$B$

Figure 1. Containers for cryopreservation: $A-$ plastic; $B-$ foil

Seeds in a container were frozen in a Dewar vessel for 1 month. During organizing cryopreservation, we used the guidelines of I.F. Zhimulev [11], V.L. Tikhonova [12], Dodonova and co-authors [13].

Thawing of seeds was carried out in two ways: 1) fast defrosting in a water bath at a temperature of 60$70{ }^{\circ} \mathrm{C}$; 2) slow defrosting at room temperature, $20-24{ }^{\circ} \mathrm{C}$. In order to determine the optimal moisture content of seeds for freezing at supercritical low temperatures, we have laid the appropriate experiments. We have frozen three types of seeds with humidity $3 ; 7$ and $12 \%$.

As the last group of experiments we studied the influence of cryoprotectors of different concentrations. The control was seeds that were frozen without the use of cryoprotectors.

Statistical processing of the results was carried out according to the method of N.L. Udolskaya [14] using the Microsoft Excel 2010 software package.

\section{Results and discussion}

Verbascum officinalis' seeds are small; $0.8-0.9 \mathrm{~mm}$ long and $0.3-0.4 \mathrm{~mm}$ wide. The weight of 1000 pieces is $0.17-0.18 \mathrm{~g}$. Form of seed is round-elliptical, the spout is obtuse; surface is rough. Color is from light brown to dark brown.

When performing the research, we examined two containers-plastic test tubes and aluminum foil bags. In the experiment, we used Verbascum officinalis' seeds with a period of storage 2 years. The initial seed germination rate was $45.3 \%$, and energy of germination was $33.0 \%$. The results showed that the germination of seeds after cryopreservation was higher than before freezing (Table 1).

\section{Germination rate and energy of germination of Verbascum officinalis' seeds depending on the container after cryopreservation}

\begin{tabular}{|l|c|c|}
\hline \multicolumn{1}{|c|}{ The conditions of the experiment } & Germination rate, $\%$ & Energy of germination, $\%$ \\
\hline Control (seeds without freezing, after 2 years of storage) & $45.3 \pm 0.8$ & $33.0 \pm 0.6$ \\
\hline Seeds after cryopreservation, frozen in plastic containers & $66.3 \pm 3.0$ & $54.0 \pm 1.9$ \\
\hline Seeds after cryopreservation, frozen in foil containers & $68.8 \pm 3.2$ & $60.4 \pm 2.7$ \\
\hline
\end{tabular}

The results of cryopreservation showed that after using plastic containers, the germination rate was $66.3 \%$ that was on $21.0 \%$ higher than in the control. The germination energy in this version of the experiment was $54.0 \%$, which was also $21.0 \%$ higher than the control data. The study of the dynamics of germination of Verbascum officinalis showed that after cryopreservation, there was a lag at the beginning of germination for 1-2 days (Fig. 2). 


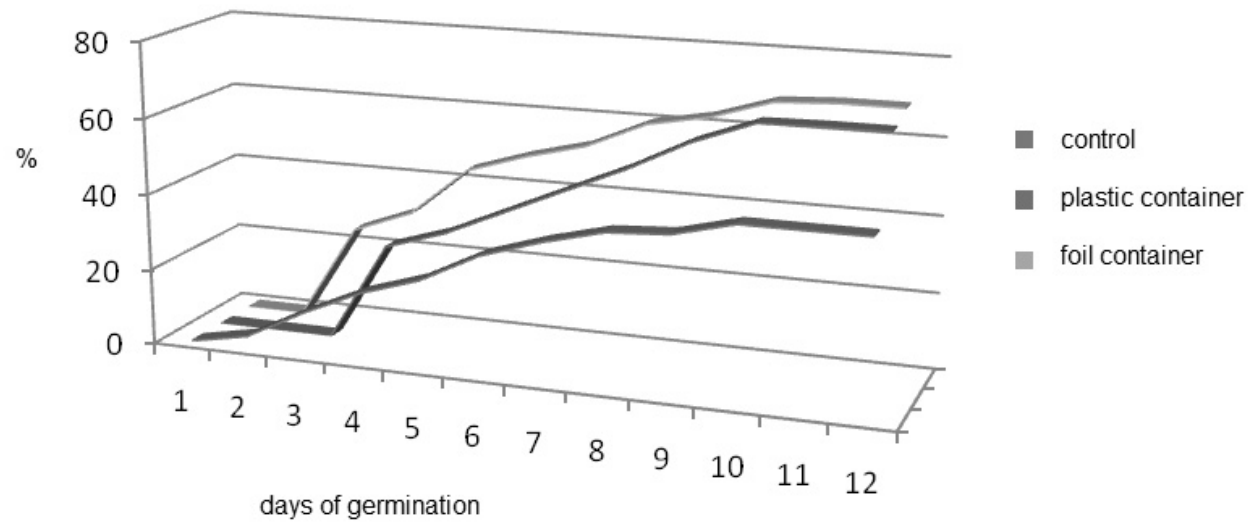

Figure 2. Dynamics of germination of Verbascum officinalis' seeds depending on the type of container

Thus, the results of research have shown that the seeds of Verbascum officinalis well tolerate to cryopreservation. The best container for freezing in liquid nitrogen is an aluminum foil container.

One of the most important conditions for maintaining the viability of seeds after freezing in liquid nitrogen is proper defrosting. We repeated experiments using two types of containers and two types of defrosting (Table 2).

Table 2

\section{Germination rate and energy of germination of Verbascum officinalis' seeds depending on types of containers and thawing conditions}

\begin{tabular}{|l|c|c|}
\hline \multicolumn{1}{|c|}{ The conditions of the experiment } & Germination rate, \% & Energy of germination, \% \\
\hline Control (seeds without freezing, after 2 years of storage) & $45.3 \pm 0.8$ & $33.0 \pm 0.6$ \\
\hline $\begin{array}{l}\text { Seeds after cryopreservation, freezing in plastic containers, } \\
\text { defrosting at room temperature }\end{array}$ & $66.3 \pm 3.0$ & $54.0 \pm 1.9$ \\
\hline $\begin{array}{l}\text { Seeds after cryopreservation, freezing in foil containers, } \\
\text { thawing at room temperature }\end{array}$ & $68.8 \pm 3.2$ & $60.4 \pm 2.7$ \\
\hline $\begin{array}{l}\text { Seeds after cryopreservation, freezing in plastic containers, } \\
\text { thawing in a water bath }\end{array}$ & $72.5 \pm 2.8$ & $54.0 \pm 1.6$ \\
\hline $\begin{array}{l}\text { Seeds after cryopreservation, freezing in foil containers, } \\
\text { thawing in a water bath }\end{array}$ & $66.3 \pm 2.2$ & $50.1 \pm 1.5$ \\
\hline
\end{tabular}

Our results showed that the maximum results were obtained in the experiment variant with using of plastic container and thawed in the water bath: germination rate was $72.5 \%$; energy of germination $54.0 \%$.

The results of cryopreservation seed with different humidity showed that the maximum results were for variant with minimum humidity $-3 \%$ (Table 3 ).

Indicators of germination rate and energy of germination of Verbascum officinalis' seeds depending on the humidity

\begin{tabular}{|c|c|c|}
\hline Humidity, $\%$ & Germination rate, $\%$ & Energy of germination, $\%$ \\
\hline 12 & $30,4 \pm 0.3$. & $19.0 \pm 0.2$ \\
\hline 7 & $56.8 \pm 2.0$ & $41.0 \pm 0.8$ \\
\hline 3 & $70.5 \pm 3.6$ & $64.3 \pm 2.2$ \\
\hline
\end{tabular}

So, in this variant the germination rate after cryopreservation was $70.5 \%$ and energy of germination was $64.3 \%$. In this variant of the experiment, the germination rate was on $40.1 \%$ higher than in variant with humidity $12 \%$; and on $13.7 \%$ higher than in variant with seed humidity $7 \%$.

Thus, for cryopreservation, it is necessary to dry the seed material until humidity $3 \%$. 
As the last group of experiments we studied the influence of cryoprotectors of different concentrations: glucose, 20 and $40 \%$; fructose, 20 and $40 \%$; sucrose 20 and $40 \%$; glycerin, 10, 20 and $40 \%$; EDTA, 5 and $10 \%$ (Table 4).

T a b le 4

\section{Germination rate and energy of germination of Verbascum officinalis' seeds after application of different cryoprotectors}

\begin{tabular}{|l|c|c|c|c|}
\hline $\begin{array}{c}\text { The variant } \\
\text { of the experiment }\end{array}$ & Germination rate, \% & $\begin{array}{c}\text { The excess over } \\
\text { the control, } \%\end{array}$ & $\begin{array}{c}\text { Energy of germina- } \\
\text { tion, } \%\end{array}$ & $\begin{array}{c}\text { The excess over the } \\
\text { control, } \%\end{array}$ \\
\hline $\begin{array}{l}\text { Control, without } \\
\text { cryoprotectors }\end{array}$ & $72.4 \pm 2.8$ & - & $66.0 \pm 3.0$ & - \\
\hline Glucose $20 \%$ & $70.5 \pm 3.2$ & -1.9 & $58.9 \pm 1.5$ & -7.1 \\
\hline Glucose 40\% & $71.3 \pm 3.4$ & -1.1 & $69.0 \pm 2.3$ & +3.0 \\
\hline Sucrose 20\% & $75.6 \pm 3.7$ & +3.2 & $60.5 \pm 2.4$ & -5.5 \\
\hline Sucrose 40\% & $65.8 \pm 2.4$ & -6.6 & $54.4 \pm 1.7$ & -11.9 \\
\hline Glycerin 10\% & $77.8 \pm 3.0$ & +5.4 & $70.1 \pm 3.1$ & +4.1 \\
\hline Glycerin 20\% & $74.2 \pm 3.3$ & +1.8 & $70.5 \pm 3.3$ & +4.5 \\
\hline Glycerin 40\% & $50.5 \pm 0.9$ & -21.9 & $45.0 \pm 0.7$ & -6.2 \\
\hline EDTA 5\% & $81.3 \pm 3.7$ & +8.9 & $70.2 \pm 3.5$ & +4.2 \\
\hline EDTA 10\% & $68.0 \pm 3.0$ & -4.4 & $55.8 \pm 1.8$ & -10.2 \\
\hline
\end{tabular}

The use of EDTA at a concentration $5 \%$ allowed increasing germination rate until $81.3 \%$ that was on $8.9 \%$ higher than the control variant. Results, which were higher than in the control variants, were conducted with using sucrose at the concentration $20 \%$, glycerin at the concentration $10 \%$ and $20 \%$. In other variants of the experiment, germination rate and energy of germination were lower than the control parametres.

Thus, the final experiments showed that the use of some cryoprotectors had the positive effect on increasing the germination rate and energy of germination. The best option for Verbascum officinalis' seeds is to use EDTA at a concentration $5 \%$.

\section{Conclusion}

Freezing the seeds of Verbascum officinalis in liquid nitrogen allowed to maintain the viability of the seed material. The best option for cryopreservation is freezing in plastic containers. The best results of survival of Verbascum officinalis' seeds were noted with rapid defrosting in a water bath (at temperature 60$70{ }^{\circ} \mathrm{C}$ ); and using seed material with humidity $3 \%$.

The using of some cryoprotectors may increase the results of germination rate and energy of germination. The best results were obtained for application DMSO in concentration $5 \%$.

According to the results of the study, the seed material of Verbascum officinalis was introduced into the seed cryo collection of medicinal plants.

The research was carried out within the framework of internal grant of E.A. Buketov Karaganda State University № 218-B-19 "Cryopreservation of vegetative and animal biological materials for development algorithm of storage of viability and creation of bank of frozen samples».

\section{References}

1 Фармацевтический рынок Казахстана: история, основные направления развития и текущее состояние. - Алматы, 2015. - $36 \mathrm{c}$.

2 Созинов А.В. Семеноводство и сертификация семян: метод. указ. для лаб.-практ. занятий / А.В. Созинов. - Лесниково: КГСХА, 2014. - 56 с.

3 Методические указания по семеноведению интродуцентов. - М.: Наука, 1980. — 64 с.

4 Овчаров К.Е. Разнокачественность семян и продуктивность растений / К.Е. Овчаров, Е.Г. Кизилов. - М.: Колос, 1966. - $160 \mathrm{c}$.

5 Николаева М.Г. Биология семян / М.Г. Николаева, И.В. Лянгузова, Л.М. Позднова. — СПб., 1999. — 232 с.

6 Николаева М.Г. Физиология и биохимия покоя и прорастания семян / М.Г. Николаева, Н.В. Обручева. - М.: Колос, 1982. - $496 \mathrm{c}$.

7 Kholina A.B. Seed cryopreservation of some medicinal legumes / A.B. Kholina, N.M. Voronkova // Journal of Botany. 2012. — Vol. 2012. — 7 p. — URL: https://doi.org/10.1155/2012/1869891. 
8 Pritchard H.W. Cryopreservation of Seeds // Cryopreservation and Freeze-Drying Protocols. Methods in Molecular Biology / H.W. Pritchard. — Totowa: Humana Press, 1995. — Vol. 38. — 133 p. — URL: https://doi.org/10.1385/0-89603-2965:133.

9 Зорина М.С. Определение семенной продуктивности и качества семян интродуцентов / М.С. Зорина, С.П. Кабанов // Методики интродукционных исследований в Казахстане. - Алма-Ата: Наука, 1986. - С. 75-85.

10 Мальцева М.В. Пособие по определению посевных качеств семян лекарственных растений / М.В. Мальцева. — М., 1950. $-56 \mathrm{c}$.

11 Жимулев И.Ф. Криохранение семян: итоги и перспективы / И.Ф. Жимулев. - Новосибирск: Изд-во СО РАН, 2014. $-112 \mathrm{c}$.

12 Тихонова В.Л. Жизнеспособность семян некоторых видов дикорастущих лекарственных растений при глубоком и неглубоком замораживании / В.Л. Тихонова, Е.В. Шугаева, В.М. Фирсанова // Растительные ресурсы. — 1996. — Т. 32 , Вып. 3. - С. 43-50.

13 Додонова А.Ш. Рекомендации по криосохранению семенного материала лекарственных и эндемичных видов растений / А.Ш. Додонова, М.Ю. Ишмуратова, Е.А. Гаврилькова, С.У. Тлеукенова. — Караганда: Полиграфист, 2017. — 120 с.

14 Удольская Н.Л. Методика биометрических расчетов / Н.Л. Удольская. - Алма-Ата: Наука, 1976. — 45 с.

\author{
С.У. Тлеукенова, Д.Ш. Байгараев, С.Н. Атикеева, А.К. Рамазанов, \\ Е.А. Гаврилькова, Р.Т. Мусина
}

\title{
Verbascum officinalis тұқымын криоконсервациялау әдісін әзірлеу
}

\begin{abstract}
Дәрілік өсімдіктерді криогендік тұқым жинағына енгізу олардың өміршеңдігін ұзақ уақыт сақтауға мүмкіндік береді. Алайда, өсімдік тұқымдарын мұздатудың әмбебап хаттамалары жоқ, яғни әр түрі үшін мұздату және жібіту шарттары жеке таңдалуы керек. Бұл зерттеудің мақсаты - Verbascum officinalis дәрілік өсімдігінің тұқымдарын криоконсервациялаудың негізгі шарттарын анықтау. Криоконсервация жағдайын жасау кезінде мұздатуға арналған оңтайлы контейнер, еріту температурасы, мұздату алдындағы тұқымның ылғалдылығы және оңтайлы криопротекторлар таңдалды. Зерттеу нәтижелері тұқымның өнгіштігі мен өну энергиясының ең жоғары көрсеткіштері пластикалық ыдысты қолдану, тұқымның ылғалдылығы 3 \% су моншасында жібіту кезінде алынғанын көрсетті. Оңтайлы криопротектор $5 \%$ концентрациядағы ДМСО болып табылады. Алынған нәтижелер дәрілік өсімдіктердің тұқымдарының криоколлекциясына Verbascum officinalis енгізуге мүмкіндік берді.
\end{abstract}

Кілm сөздер: дәрілік өсімдік, Verbascum officinalis, тұқымның өнгіштігі, өну энергиясы, тұқымның ылғалдылығы, криоконсервация, ыдыстың түрі, жібіту, криопротекторлар.

\section{С.У. Тлеукенова, Д.Ш. Байгараев, С.Н. Атикеева, А.К. Рамазанов, Е.А. Гаврилькова, Р.Т. Мусина \\ Разработка метода криоконсервации семян Verbascum officinalis}

\begin{abstract}
Введение в криогенную коллекцию семян лекарственных растений позволяет сохранять их жизнеспособность длительное время. Однако не существует универсальных протоколов замораживания семян растений, то есть для каждого вида условия замораживания и размораживания нужно подбирать индивидуально. Цель настоящего исследования - определить основные условия криоконсервации семян лекарственного растения Verbascum officinalis. При разработке условия криоконсервации выбирали оптимальную тару для замораживания, температуру для размораживания, влажность семян перед заморозкой и оптимальные криопротекторы. Результаты исследований показали, что максимальные показатели всхожести семян и энергии прорастания получены при применении пластиковой тары, влажности семян $3 \%$, размораживании на водяной бане. Оптимальным криопротектором является ДМСО в концентрации 5 \%. Полученные результаты позволили ввести Verbascum officinalis в криоколлекцию семян лекарственных растений.
\end{abstract}

Ключевые слова: лекарственное растение, Verbascum officinalis, всхожесть семян, энергия прорастания, влажность семян, криоконсервация, тип тары, размораживание, криопротекторы.

\section{References}

1 Farmatsevticheskii rynok Kazakhstana: istoriia, osnovnye napravleniia razvitiia i tekushchee sostoianie [Pharmaceutical market of Kazakhstan: history, basic direction and current state]. (2015). Almaty [in Russian]. 
2 Sozinov, A.V. (2014). Semenovodstvo i sertifikatsiia semian: metodicheskie ukazaniia dlia laboratorno-prakticheskikh zaniatii [Seed production and certification of seeds: guidelines for laboratory and practical training]. Lesnikovo: KGSCA [in Russian].

3 Metodicheskie ukazaniia po semenovedeniiu introdutsentov [Mannual for seed breading of introduced plants]. (1980). Moscow: Nauka [in Russian].

4 Ovcharov, K.E., \& Kizilov, E.G. (1966). Raznokachestvennost semian i produktivnost rastenii [Different quality of seeds and plant productivity]. Moscow: Kolos [in Russian].

5 Nikolaeva, M.G., Lyanguzova, I.V., \& Pozdnova, L.M. (1999). Biolohiia semian [Seed biology]. Saint Petersburg [in Russian].

6 Nikolaeva, M.G., \& Obrucheva, N.V. (1982). Fiziolohiia i biohimiia pokoia i prorastaniia semian [Physiology and biochemistry of seed germination]. Moscow: Kolos [in Russian].

7 Kholina, A.B., \& Voronkova, N.M. (2012). Seed cryopreservation of some medicinal legumes. Journal of Botany, 2012, 7 , URL: https://doi.org/10.1155/2012/1869891

8 Pritchard, H.W. (1995). Cryopreservation of Seeds. Cryopreservation and Freeze-Drying Protocols. Methods in Molecular Biology, 38, 133. Totowa: Humana Press. URL: https://doi.org/10.1385/0-89603-296-5:133.

9 Zorina, M.S., \& Kabanov, S.P. (1986). Opredelenie semennoi produktivnosti i kachestva semian introdutsentov [Determination of seed productivity and quality of seeds of introduced plants]. Metodiki introduktsionnykh issledovanii v Kazakhstane - Methodology of introduction study in Kazakhstan. Alma-Ata: Nauka [in Russian].

10 Malceva, M.V. (1950). Posobie po opredeleniiu posevnykh kachestv semian lekarstvennykh rastenii [Manual for determining the sowing qualities of medicinal plant seeds]. Moscow [in Russian].

11 Zhimulyev, I.F. (2014). Kriokhranenie semian: itohi i perspektivy [Cryopreservation of seeds: results and perspectives]. Novosibirsk: Siberian Department of RAS Publ. [in Russian].

12 Tikhonova, V.L., Shugayeva, E.G., \& Firsanova, B.M. (1996). Zhiznesposobnost semian nekotorykh vidov dikorastushchikh lekarstvennykh rastenii pri hlubokom i nehlubokom zamorazhivanii [Viability of seeds of some wild medicinal plants for deep and non-deep freezing]. Rastitelnye resursy - Plant Resources, 32(3), 43-50 [in Russian].

13 Dodonova, A.Sh., Ishmuratova, M.Yu., Gavrilkova E.A., \& Tleukenova, S.U. (2017). Rekomendatsii po kriosokhraneniiu semennoho materiala lekarstvennykh i endemichnykh vidov rastenii [Recommendations for the preservation of seed material of medicinal and endemic plant species]. Karaganda: Polihrafist [in Russian].

14 Udolskaya, N.L. (1976). Metodika biometricheskikh raschetov [Biometric Calculation Methodology]. Alma-Ata: Nauka [in Russian]. 